\title{
Acceptance of fish hamburgers in school meals in the Southwest Region of Paraná, Brazil
}

\author{
Leandra Schuastz BREDA ${ }^{1}$, Anne Caroline BELUSSO ${ }^{1}$, Barbara Arruda NOGUEIRA ${ }^{1}$,

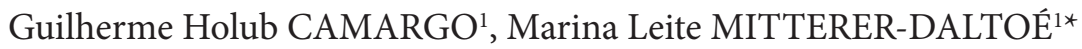

\begin{abstract}
The regular consumption of fish provides health gains for people, and its introduction in school meals is an important strategy to insert the habit of consuming this food by a population. Thus the objective of this study was to verify the acceptance of fish, presented in the form of hamburger, by children in municipal primary schools in the town of Pato Branco, Brazil, in which the school cooks had been trained to produce fish hamburgers. Acceptance was evaluated using a hedonic scale with 5 facial classifications $(1=$ disliked extremely to $5=$ liked extremely). Students of both genders from 5 to 10 years of age $(n=142)$ were served the hamburgers for their midday meal, representing the protein portion of the meal. The results were analyzed by logistic regression. No effect of age or gender was observed between the children in the acceptance of the hamburgers, but the interaction between age and gender was significant. The cluster analysis was applied to distinguish this interaction using two-way joining to present the results, which showed the effect between specific age and gender situations. The acceptance index was $87 \%$ showing the potential for the consumption of this food by children.
\end{abstract}

Keywords: fish; hamburger; school meals; acceptance; children.

Practical Application: To increase fish consumption in a region, school meals emerges as an important strategy.

\section{Introduction}

Fish is a food of high nutritional value, characterized by presenting components necessary for the human organism, such as mineral salts, high biological value proteins and fatty acids, principally the polyunsaturated ones of the omega 3 and omega 6 families (Bonacina \& Queiroz, 2007; Pilon et al., 2011; Sampels, 2015). The ingestion of fish has been related to the prevention of heart and brain problems (Nestel et al., 2015).

Fish consumption varies from one region in Brazil to another, from the north where the consumption is three times greater than the $12 \mathrm{~kg} /$ inhabitant/year suggested by FAO, to the south, where consumption is three times less than in the north (Sartori \& Amancio, 2012). These numbers are far from those indicated, suggesting the need to develop the habit of fish consumption in the region.

It is known that preferences formed in childhood normally continue into adulthood, and that children are more receptive to changes in food habits than adults (Baxter et al., 2000). Thus the Brazilian National School Meals program (PNAE), whose objectives are to contribute to biopsychosocial growth and development, learning, school performance and the formation of healthy food habits by way of the offer of adequate school meals (Brasil, 2015), appears as an important strategy for insertion of the fish consumption habit in any region characterized by low consumption of this food.
Processed fish transformed into a derived product figures as a good strategy for the introduction of fish consumption in school meals (Latorres et al., 2016; Mitterer-Daltoé et al., 2013a). Earlier works revealed a positive relationship between appearance and positive hedonic perception by children with respect to fish derivatives (Donadini et al., 2013; Latorres et al., 2016). These authors reported that appearance was the key attribute in the acceptance of fish by children, and highlighted the fact that the visual qualities of foods generate expectations about the flavor. Other advantages can be pointed out, such as the elimination of fish bones and a decrease in the characteristic odor of fish, such attributes being characterized as barriers to fish consumption (Belusso et al., 2016). In addition, another benefit of fish products is the possibility of presenting high nutritional value (Belusso et al., 2016; Corbo et al., 2008; Mitterer-Daltoé et al., 2014).

Part of the process of inserting a food into school meals is the evaluation of its acceptance by way of hedonic tests (Latorres et al., 2016; Mitterer-Daltoé et al., 2013a). Hedonic scales are used to quantify the affective dimension (Latorres et al., 2016; Lim, 2011; Peryam \& Pilgrim, 1957; Tuorila et al., 2008) and in the case of children facial scales are used (Latorres et al., 2016; Mitterer-Daltoé et al., 2013a), since youngsters are incapable of using verbal scales efficiently, and also the images employed 
are diverting and inspire more attention with respect to the test (Popper \& Kroll, 2005). Facial hedonic scales are scales with illustrated categories, where each verbal category which makes up the traditional scale proposed by Peryam \& Pilgrim (1957), is substituted by a child's facial expression, demonstrating a certain degree of satisfaction or dissatisfaction. The facial expressions anchored in each category suggest a growing continuum of satisfaction. On using this scale, the child should choose the expression that corresponds to his/her own degree of satisfaction or dissatisfaction with respect to the product evaluated.

Having verified the importance of fish for human health and conscious of the importance of healthy eating habits in childhood, the objective of the present work was to evaluate the acceptance of fish in the form of hamburger in school meals for children from 5 to 10 years of age.

\section{Material and method}

\subsection{Raw material}

The raw material, tilapia fillet (Oreochromis niloticus), was acquired from rural producers in the city of Pato Branco, Brazil, for use in the training course for school cooks to learn how to elaborate the fish products, and also to prepare the fish products themselves for the evaluation of their acceptance in the school meals. The acquisition was made by the local council according to Law 11.947/209 entitled the National School Meals Program (PNAE) (Brasil, 2009), which states that a minimum of $30 \%$ of the value transferred to the states and municipalities by the National Education Development Fund (FNDE) via PNAE be used to buy food produced by family agriculture. This partnership aims to provide fresh, varied high quality food for the preparation of school meals, and concomitantly foment national family agriculture (Brasil, 2015, 2016).

\subsection{Training of the school cooks to elaborate fish hamburgers}

School cooks were trained to prepare fish hamburgers in three municipal schools in the town of Pato Branco, such that these trained cooks would be able to pass on their knowledge to other school cooks in the town. The training consisted of a theoretical part followed by the practical execution.

\section{Theoretical capacitation}

The theoretical capacitation considered the advantages of transforming the fish fillet into fish hamburgers, such as the increase in shelf life and the safety provided to the children by the absence of fish bones. Themes such as: definition of a processed product; legislation for processed fish products; formulation for the elaboration of fish hamburgers; function of the ingredients in the formulation of fish hamburger; and notions concerning good handling practices were considered. Table 1 gives an example of a formulation calculated to yield fifty $100 \mathrm{~g}$ hamburgers.

\section{Practical capacitation and elaboration of the fish hamburgers}

The practical capacitation for the elaboration of the hamburgers included basic food handling, weighing (Metalúrgica DAK, DST15-DM) of the ingredients, homogenization in an industrial blender (METVISA- LAR.2, 3450RPM), molding in the hamburger format in round aluminum molds ( $12.5 \mathrm{~cm}$ diameter, $1 \mathrm{~cm}$ thickness), weighing approximately $100 \mathrm{~g}$ each, and conservation for quick consumption as shown in Figure 1.

The following day, the preparation of the hamburgers by the cooks for consumption and the acceptance test by the children was accompanied. The hamburgers were baked in an electric oven (Progás, Inteligente Light) until reaching an internal temperature of $72{ }^{\circ} \mathrm{C}\left(180{ }^{\circ} \mathrm{C}\right.$ for $\left.40 \mathrm{~min}\right)$ and served $(100 \mathrm{~g}$ at $55^{\circ} \mathrm{C}$ ) sequentially, during school lunch at lunchtime together with rice, beans and a green salad (lettuce or cabbage).

\subsection{Proximate characterization of the fish hamburgers}

The fish hamburgers were characterized with respect to the proximate composition and caloric value. The proximate analysis was based on the following parameters: moisture content, ash content and proteins as from the determination of total nitrogen (Association of Official Analytical Chemists, 1990). The lipids

Table 1. Formulation for the elaboration of fifty $100 \mathrm{~g}$ hamburgers.

\begin{tabular}{lcc}
\hline \multicolumn{1}{c}{ Ingredients } & Quantity $(\mathrm{g})$ & Percentage $(\%)$ \\
\hline Fish fillet & 3962.50 & 79.25 \\
Ice & 500.00 & 10.00 \\
Salt & 50.00 & 1.00 \\
Vegetable fat & 250.00 & 5.00 \\
Texturized protein & 150.00 & 3.00 \\
Dehydrated onion & 37.50 & 0.75 \\
Garlic powder & 25.00 & 0.50 \\
Dehydrated parsley & 25.00 & 0.50 \\
Total & 5000.00 & 100.00 \\
\hline
\end{tabular}

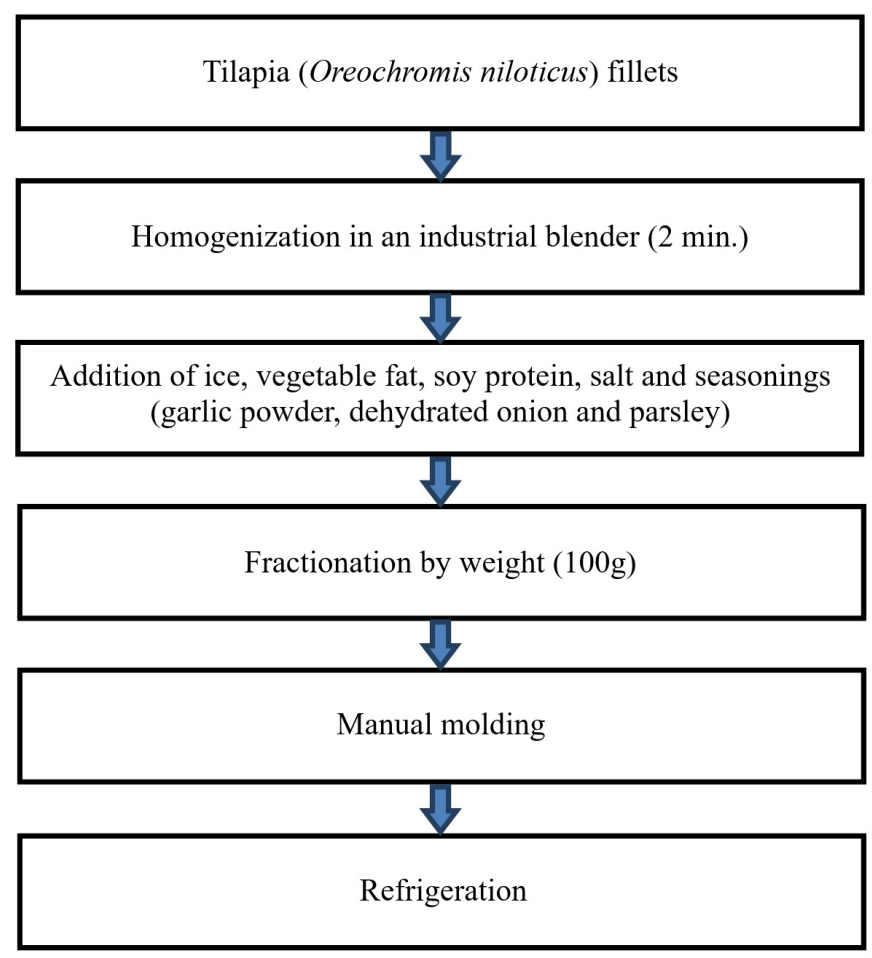

Figure 1. Flow diagram for the elaboration of fish hamburger. 
were quantified using the Bligh \& Dyer (1959) method and the carbohydrate content obtained by difference. The caloric value of each formulation was calculated as from the concentrations of protein, lipids and carbohydrates, considering conversion factors of $4 \mathrm{kcal} . \mathrm{g}^{-1}$ for protein and carbohydrate and $9 \mathrm{kcal} . \mathrm{g}^{-1}$ for lipids (Merril \& Watt, 1973).

\subsection{Hedonic evaluation of the fish hamburgers}

After the meal the hedonic test was carried out individually with each child $(n=142)$ using the 5 point facial structured hedonic scale to evaluate acceptance of the fish hamburgers (Figure 2). These 142 students, aged between 5 and 10 years, correspond to all the children who perform lunch at school. The children were requested to choose the facial expression that best symbolized their opinion with respect to the hamburger they just ate. Data referring to age and gender were also filled in on the scorecard.

The results of research involving humans were approved by the Ethics Committee for Human Research at the Universidade Tecnológica Federal do Paraná (case number 084859/2014).

\subsection{Statistical analyses}

The acceptance index (AI) was calculated as from the mean value obtained, where the maximum value on the scale (5) became 100\% (Mitterer-Daltoé et al., 2013a). Multinomial logistic regression analysis was applied to evaluate the effect of the variables of age and gender on the acceptance of the fish derivative (Latorres et al., 2016), and a two-way joining cluster analysis to evaluate the interaction between the two. The data were analyzed using Statistica 12.7.

\section{Results and discussion}

\subsection{Nutritional characterization of the fish hamburger}

Table 2 shows the proximate composition of the tilapia hamburgers elaborated by the school cooks, and also the caloric value in $\mathrm{kcal} / 100 \mathrm{~g}$, calculated using the Atwater factors
(4, 4 and 9) for proteins, carbohydrates and lipids, respectively (Merril \& Watt, 1973).

It is important to determine the composition of a food since it has a direct influence on the evaluation of the food supply and consumption of a country, this being the parameter used for the dietetic adjustment of people and populations and their nutritional status, verifying relationships between consumption options and diseases as well as serving as a basis for the technological planning of industries, farming and husbandry (Torres et al., 2000).

Another important question to evaluate is conformity of the product with the legislation, such that it reaches the minimum quality characteristics that characterize it. The concentrations found in the hamburgers in the present study conformed with the identity and quality technical regulations for hamburgers (Brasil, 2000). This document fixes a minimum value for protein of $15 \%$ in hamburgers, and maximum values for carbohydrates, lipids and ash of 3,23 and $0.1 \%$, respectively. With respect to the lipid content, it should be noted that the tilapia hamburgers showed values considerably lower than the maximum value permitted by the technical regulation, a positive result from the caloric point of view.

Although it is known that a large part of the fat quantified did not come from the tilapia fish itself (see Table 1), the portion originating from the tilapia was characterized by an elevated nutritional value and by health benefits such as a reduction in

Table 2. Proximate composition and caloric value of the raw tilapia hamburgers.

\begin{tabular}{lcc}
\hline \multicolumn{1}{c}{ Nutrients } & $\%$ & $\begin{array}{c}\text { Caloric value } \\
(\mathrm{kcal} / 100 \mathrm{~g})\end{array}$ \\
\hline Moisture & 74.60 & - \\
Ash & 00.98 & - \\
Protein & 15.52 & 62.08 \\
Lipids & 05.89 & 53.01 \\
Carbohydrates & 3.01 & 12.0 \\
Total & & 127.09 \\
\hline
\end{tabular}

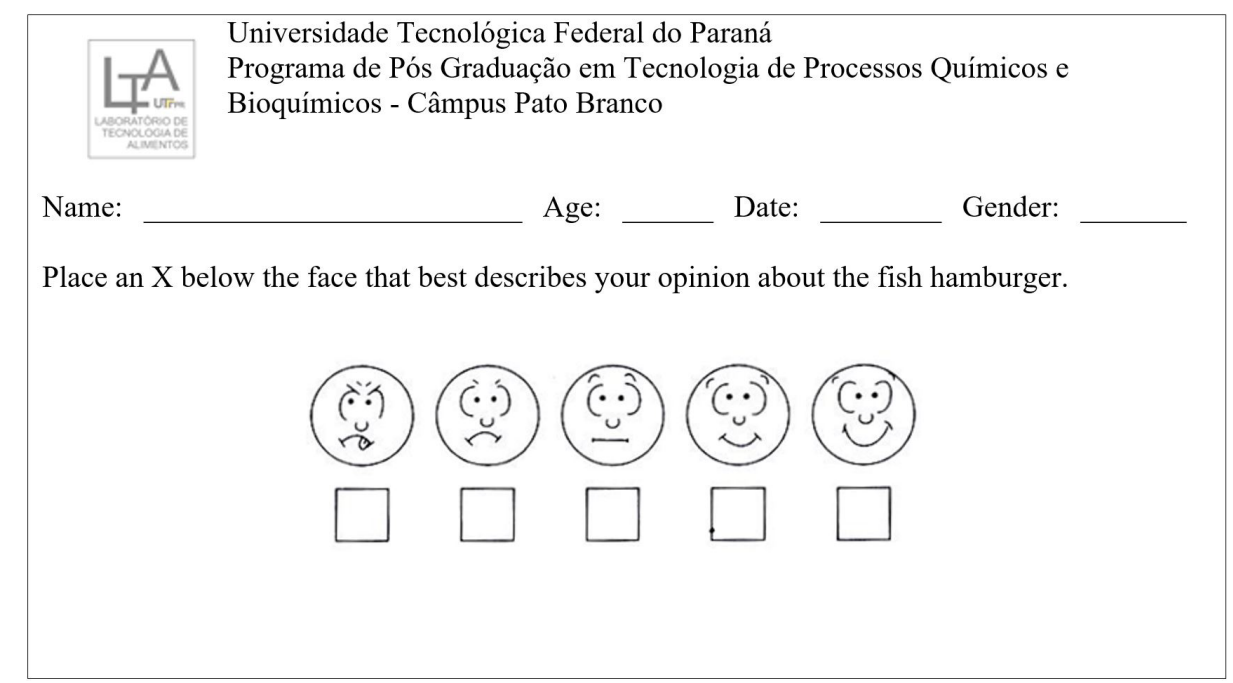

Figure 2. Structured 5 point facial hedonic scorecard used by the children to evaluate the fish hamburgers (Dutcosky, 2007). 
risk factors associated with cardiovascular diseases, thrombosis, inflammations, depression and cancer (Andrade et al., 2009; Fernandes et al., 2014; Memon et al., 2011), due to the presence of high unsaturated and polyunsaturated fatty acid contents, characteristic of fish lipids. Beside, it is noteworthy that this is a characteristic of tilapia and fish hamburgers can be made from other fish characterized by having higher lipid content.

As in the case of the lipids, fish proteins are of high quality, rich in essential amino acids (Fernandes et al., 2014), and characterized by an elevated biological value and high digestibility (Food Ingredients Brasil, 2009; Halim et al., 2016; Simões et al., 1998; Soares \& Gonçalves, 2012). Since the protein portion was very similar to that of the fish fillet (15.52\%) (Food Ingredients Brasil, 2009), the tilapia hamburger presented itself as an important protein source to be offered to the children.

However, it should be mentioned that in the same way as fish proteins are evidently of high nutritional value, they are also characterized by their ease in degradation, due to hydrolysis by endogenous muscle enzymes and the action of microorganisms that degrade nitrogenous compounds forming ammonia, trimethylamine and other compounds (Cicero et al., 2014; Soares \& Gonçalves, 2012). These characteristics together with the high moisture content of the hamburgers $(74.60 \%)$ demand attention, such that they are produced rapidly and immediately stored under refrigeration or frozen, to avoid microbial proliferation and guarantee preservation of their freshness.

The caloric value found for the tilapia hamburgers ( 127.09 calories) was below that found for mixed (beef/ pork) and chicken hamburgers, which presented values of 229.9 and 162.25 calories, respectively (Torres et al., 1998), values close to those reported by Borba et al. (2013) of 223.27 calories/ $100 \mathrm{~g}$ for bovine hamburgers and 165.69 calories/ $100 \mathrm{~g}$ for chicken hamburgers.

Hamburgers, currently widely used in feeding due to their practicality Borba et al. (2013), carry with them a negative health perception due to views against processed products (Mitterer-Daltoé et al., 2014). This concern brings to the surface one of the worries related to modern feeding, that of the elevated weight gains by diverse populations (Chandon \& Wansink, 2007), a phenomenon frequently related to the constantly increasing consumption of pre-prepared foods with a composition unbeknown to the consumer.

The hamburger is a popular fast food and can present significant variations in its caloric value according to its formulation (Leonardi et al., 2009) and the type of raw meat material employed, characterized by a variation in the lipid/ moisture contents ratio (Bernardino et al., 2014). The offer of information and the habit of analyzing the composition and caloric value have therefore become important factors, and according to Wei \& Miao (2013), the consumer tends to make better choices of his food when he/ she has access to information regarding the calorie content of the food he/ she would like to eat. Thus a fish hamburger, considered as processed food but with good nutritional potential, could indeed be an appetizing, healthy and fun-type food.

\subsection{Application of the facial hedonic test in children from the local school network to evaluate fish hamburgers}

Table 3 shows the characteristics of the children who took part in the facial hedonic test to evaluate the acceptance of fish hamburger. The tests were applied to a total of 142 children aged between 5 and 10 years old, from three municipal schools in the town of Pato Branco, of which 81 were girls and 61 boys. The acceptance index registered of $87 \%$ verified the potentiality of inserting the fish hamburger into the school meals, this value being very close to the minimum of $90 \%$ demanded by the Manual for the Application of Acceptability Tests of the National School Meals Program - PNAE (Universidade Federal de São Paulo, 2010).

Earlier studies already showed the potentiality of consuming fish derivatives in Brazilian public schools (Latorres et al., 2016; Mitterer-Daltoé et al., 2013a). Mitterer-Daltoé et al. (2013a) evaluated the acceptance of fish nuggets by 5 to 18 year old schoolchildren from two different towns in the State of Rio Grande do Sul, Brazil, one on the coast with its economy mainly based on port activities, and the other in the sierras in the southeast of the state, where the economy is based mainly on mining, agriculture and cattle raising activities. The authors registered acceptance indexes of $84 \%$ for the coastal town and $80 \%$ for the other town, and highlighted the non-significant difference between the results from the two towns. In another trial, Latorres et al. (2016) found an acceptance index equal to that found in the present study $(87 \%)$ for fish balls served to 6 to 14 year old schoolchildren in their school meals. Both studies highlighted the potentiality of inserting fish derivatives into the school meals.

It should be pointed out that, since fish is a food that is not part of the eating habits in the region under study (Mitterer-Daltoé et al., 2013b), acceptance indexes above 80\% can be considered promising both for insertion of this protein source into school meals and to increase the consumption of this food by the regional population, since school meals can exert an important effect on transforming the eating habits of a population (Benn \& Carlsson, 2014; Bertin et al., 2010; Maietta \& Gorgitano, 2016; Medeiros et al., 2011).

Table 3. Hedonic evaluation of fish hamburgers by schoolchildren - $\mathrm{N}=142$.

\begin{tabular}{ccc}
\hline Variables & & Frequency \\
\hline Gender & Female & 81 \\
Age & Male & 61 \\
& 5 & 18 \\
& 6 & 19 \\
& 7 & 27 \\
Acceptance & 8 & 31 \\
& 9 & 28 \\
& 10 & 19 \\
& 1 & 10 \\
& 2 & 04 \\
& 3 & 09 \\
& 4 & 23 \\
& 5 & 96 \\
\hline
\end{tabular}


The multinomial logistic regression analysis was applied to explore the effects of the variables of age and gender and of the interaction between them on the acceptance of the fish hamburgers by the children (Table 4). The logistic regression analysis is considered to be a robust technique and can be applied in different situations in which the dependent variable is qualitative and the independent variables are continuous, discrete, categorical, dichotomous or a mixture of all of these (González et al., 2011). The significance of each coefficient is given by the Wald test. If the logistic coefficient is statistically significant, its interpretation is in terms of how it affects the dependent variable (Hair et al., 2009).

According to the results shown in Table 4 , the variables of age and gender showed no significant effect $(p \geq 0.05)$ on the variation in acceptance of the fish hamburgers by the schoolchildren. In the study presented by Mitterer-Daltoé et al. (2013a), where the authors evaluated the acceptance of fish nuggets in school meals, no significant effect of the variable of gender was found, but the variable of age showed a highly significant effect on the variation in acceptance. However, on exploring the behavior of age on acceptance using a box plot, the authors found that up to the age of 11 the mean acceptance index was maintained at $100 \%$, and the behavior started to change as from 12 years of age, an age considered critical by some authors, for representing the start of the fish rejection process (Myrland et al., 2000) and for presenting hedonic scores compatible with those of adults (Peterson et al., 2006).

In the present study the age of the children varied from 5 to 10 years of age, an age range considered predisposed to receiving new foods (Tuorila et al., 2015), especially fish (Latorres et al., 2016; Mitterer-Daltoé et al., 2013a; Myrland et al., 2000), and hence no significant relationship was found (negative or positive) between an increase in acceptance of the fish hamburgers and the age of the schoolchildren. According to Tuorila et al. (2015), with the approach of adolescence (12 years of age), the students become more critical in relation to the quality of their meals and show negative attitudes with respect to school meals, presenting a stereotyped perception that they are bad and of low quality (Osowski et al., 2013).

Amongst the independent variables, the age* gender interaction presented a significant effect on acceptance of the fish hamburgers by the schoolchildren, and hence the multivariable technique known as the two-way joining cluster analysis was used to better explore this behavior (Figure 3).

Cluster or grouping analyses are procedures commonly used to segment consumers. In the cluster analysis the consumers are classified in relatively homogeneous groups such that the individuals remaining together in the same cluster show similarities one with the other (Müller \& Hamm, 2014; Onwezen \& van der Weele, 2016). According to Naes et al. (2010) one important aspect of the cluster analysis within the sensory analysis and consumer science area is that can rarely expect clearly separated agglomerates. Thus the main objective of applying the two-way joining cluster analysis in the present study was to identify individuals (gender + age) who were more similar one to the other with respect to acceptance of the fish hamburgers, and not necessarily find homogeneous groups.

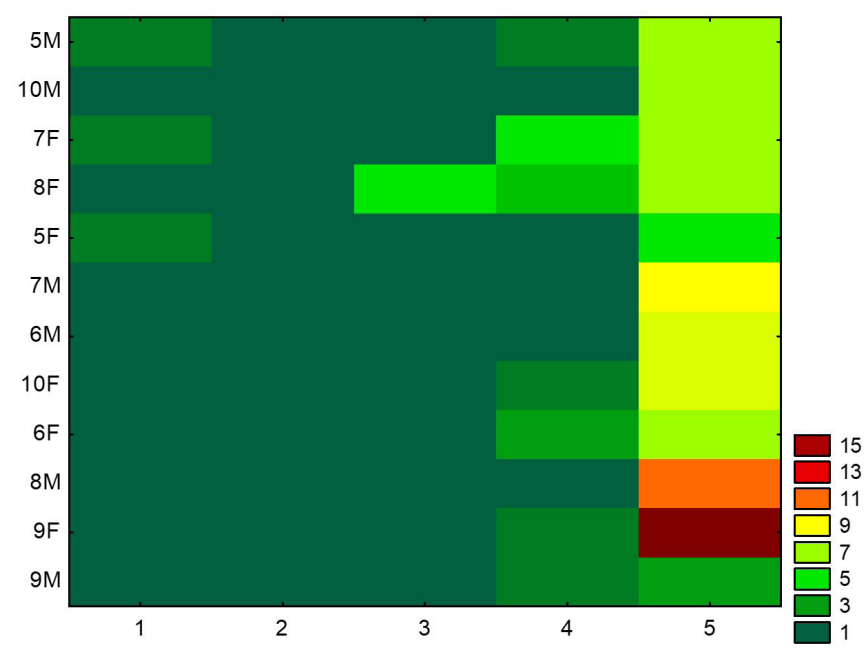

Figure 3. Result of the two-way joining cluster analysis - ages from 5 to 10 years old - genders: F (female) \& M (male).

Table 4. Statistical significance of the variables of gender and age and of gender ${ }^{\star}$ age in the acceptance of fish hamburgers.

\begin{tabular}{lcc}
\hline \multicolumn{1}{r}{ Effect } & Wald & P \\
\hline Age & 01.72933 & 0.785384 \\
Gender & 03.69291 & 0.449158 \\
Age x Gender & 14.36093 & 0.006228 \\
\hline
\end{tabular}

$\mathrm{p} \leq 0.05$ indicates a significant effect of the independent variables on acceptance.

The results revealed in Figure 3 express the clusters formed, where the intensity of the color indicates in which hedonic score the child (female or male) of a determined age was best related. If one evaluates the maximum point on the hedonic scale (5) one can see a greater intensity of marks for all the age ${ }^{\star}$ gender interactions and a greater variation in the heat maps, a result that was expected considering the acceptance index of $87 \%$.

These results corroborate the gender*age interaction previously determined by the logistic regression, and this significant interaction becomes evident when the ages of 8 and 9 are analyzed. For point 5 on the scale and an age of 9 , there was a clear difference between the genders, boys showing a frequency of marks of 3 and girls of 15 . The inverse behavior, but with less difference, was observed for the age of 8 , boys showing a frequency of marks equal to 11 and girls equal to 7 .

The effect of the interaction between gender and age in sensory perception was also verified in the work of James et al. (1997). With the objective of comparing the abilities of 8 and 9 year old children and of adults in the perception of different basic tastes, the authors found no significant differences between adult men and women or between girls and women. However, the boys ( 8 and 9 year olds) showed a significantly higher threshold for all the basic tastes than the women; for all the tastes with the exception of bitter as compared to the men; and for the tastes of salty and sweet in relation to the girls. According to the researchers the boys were far below the girls of the same age with respect to their abilities to recognize basic tastes. 
Smaller differences in the marks were found for the ages of 5, 6, 7 and 10 between the genders for point 5 on the scale. This result confirms even more the behavior found previously, which did not establish an effect for the variation of age and gender but did for the interaction between the two variables in the acceptance of the fish hamburgers by the schoolchildren.

\section{Conclusions}

It was concluded that the tilapia hamburgers configured as an important option for fish derivatives to be inserted into school meals, since they presented a high nutritional value, low caloric value and an acceptance index of $87 \%$ amongst the schoolchildren of the municipal network in the city of Pato Branco, Brazil.

\section{Acknowledgements}

The authors are grateful to the National Council for Scientific and Technological Development - CNPq - Brasil (Process Universal no 456102/2014-0).

\section{References}

Andrade, G. Q., Bispo, E. S., \& Druzian, J. I. (2009). Avaliação da qualidade nutricional em espécies de pescado mais produzidas no Estado da Bahia. Food Science and Technology (Campinas), 29(4), 721-726.

Association of Official Analytical Chemists - AOAC. (1990). Official Methods of Analysis of the Association of Official Analytical Chemists (Vol. 1, 15th ed.). Gaithersburg: AOAC.

Baxter, I. A., Schroder, M. J. A., \& Bower, J. A. (2000). Children's perceptions of and preferences for vegetables in the west of scotland : the role of demographic factors. Faculty of Business \& Consumer Studies, 15, 361-381.

Belusso, A. C., Nogueira, B. A., Breda, L. S., \& Mitterer-Daltoé, M. L. (2016). Check all that apply (CATA) as an instrument for the development of fish products. Food Science and Technology (Campinas), 36(2), 1-7. http://dx.doi.org/10.1590/1678-457X.0026.

Benn, J., \& Carlsson, M. (2014). Learning through school meals? Appetite, 78, 23-31. PMid:24656948. http://dx.doi.org/10.1016/j. appet.2014.03.008.

Bernardino, R. Fo, Queiroga, A. X. M., Gomes, Q. O., Pereira, B. B. M., \& Maracajá, P. B. (2014). Elaboração de hambúrguer formulado com filé de peixe tucunaré (cichla ssp.). Revista Verde de Agroecologia E Desenvolvimento Sustentável, 9(3), 75-80.

Bertin, R., Malkowski, J., Zutter, L., \& Ulbrich, A. (2010). Estado nutricional, hábitos alimentares e conhecimentos de nutrição em escolares. Revista Paulista de Pediatria: Orgao Oficial da Sociedade de Pediatria de Sao Paulo, 28(3), 303-308. http://dx.doi.org/10.1590/ S0103-05822010000300008.

Bligh, E. G., \& Dyer, W. J. (1959). A rapid method of total lipid extraction and purification. Canadian Journal of Biochemistry and Physiology, 37(8), 911-917. PMid:13671378. http://dx.doi.org/10.1139/o59-099.

Bonacina, M., \& Queiroz, M. I. (2007). Elaboração de empanado a partir da corvina (Micropogonias furnieri). Food Science and Technology (Campinas), 27(3), 544-552.

Borba, C. M., Oliveira, V. R., Montenegro, K. R., Hertz, P. F., \& Venzke, J. G. (2013). Avaliação físico-química de hambúrguer de carne bovina e de frango submetidos a diferentes processamentos térmicos. Braz. J. Food Nutr, 24(1), 21-27.
Brasil. Ministério da Agricultura, Pecuária e Abastecimento. (2000). Instrução Normativa no 20. Aprova os Regulamentos Técnicos de Identidade e Qualidade de Almôndega, de Apresuntado, de Fiambre, de Hambúrguer, de Kibe, de Presunto Cozido e de Presunto. Diário Oficial [da] República Federativa do Brasil, seção 1.

Brasil. Ministério do Planejamento, Orçamento e Gestão. (2009). Lei $\mathrm{n}^{\circ}$ 11.947/2009, (Lei Ordinária) 16 de junho de 2009. Dispõe sobre o atendimento da alimentação escolar e do programa dinheiro direto na escola aos alunos da educação básica. Diário Oficial [da] República Federativa do Brasil.

Brasil. (2015). Cartilha Nacional da alimentação escolar (2. ed., 84 p.). Brasília, DF: Ministério da Educação, Fundo Nacional do Desenvolvimento da Educação.

Brasil. (2016). Aquisição de produtos da agricultura familiar para a alimentação escolar (2. ed., 21 p.). Brasília, DF: Ministéro da Educação, Fundação Nacional do Desenvolvimento da Educação.

Chandon, P., \& Wansink, B. (2007). The biasing health halos of fastfood restaurant health claims: lower calorie estimates and higher side-dish consumption intentions. The Journal of Consumer Research, 34(October), 301-314. http://dx.doi.org/10.1086/519499.

Cicero, L. H., Furlan, E. F., Tomita, R. Y., Prisco, R. C. B., Savoy, V. L. T., \& Neiva, C. R. P. (2014). Estudo das metodologias de destilação na quantificação do Nitrogênio das Bases Voláteis Totais em pescada, tilápia e camarão. Food Technology, 17(3), 192-197.

Corbo, M. R., Speranza, B., Filippone, A., Granatiero, S., Conte, A., Sinigaglia, M., \& Del Nobile, M. (2008). Study on the synergic effect of natural compounds on the microbial quality decay of packed fish hamburger. International Journal of Food Microbiology, 127(3), 261-267. PMid:18804302. http://dx.doi.org/10.1016/j. ijfoodmicro.2008.07.014.

Donadini, G., Fumi, M., \& Porretta, S. (2013). Hedonic response to fish in preschoolers. Journal of Sensory Studies, 28(4), 282-296. http:// dx.doi.org/10.1111/joss.12043.

Dutcosky, S. D. (2007). Análise sensorial de alimentos (2nd ed., 239 p.). Curitiba: Champagnat.

Fernandes, C. E., Vasconcelos, M. A. D. S., Ribeiro, M. D. A., Sarubbo, L. A., Andrade, S. A. C., \& Melo, A. B. D. Fo (2014). Nutritional and lipid profiles in marine fish species from Brazil. Food Chemistry, 160, 67-71. PMid:24799210. http://dx.doi.org/10.1016/j.foodchem.2014.03.055.

Food Ingredients Brasil. (2009). Propriedades funcionais das proteínas do peixe. Revista-fi, 8, 23-32.

González, C., Liste, A., \& Felpeto, A. (2011). Tratamiento de datos con $R$, statistics y SPSS. Espanha: Diaz de Santos.

Hair, J., Black, W., Babin, B., Anderson, R., \& Tatham, R. (2009). Análise multivariada de dados (6th ed.). Porto Alegre: Bookman.

Halim, N. R. A., Yusof, H. M., \& Sarbon, N. M. (2016). Functional and bioactive properties of fish protein hydolysates and peptides: a comprehensive review. Trends in Food Science \& Technology, 51, 24-33. http://dx.doi.org/10.1016/j.tifs.2016.02.007.

James, C., Laing, D., \& Oram, N. (1997). A comparison of the ability of 8-9-year-old children and adults to detect taste stimuli. Physiology \& Behavior, 62(1), 193-197. PMid:9226362. http://dx.doi.org/10.1016/ S0031-9384(97)00030-9.

Latorres, J. M., Mitterer-daltoé, M. L., \& Queiroz, M. I. (2016). Hedonic and word association techniques confirm a successful way of introducing fish into public school meals. Journal of Sensory Studies, 31(3), 1-8. http://dx.doi.org/10.1111/joss.12204.

Leonardi, D. S., Feres, B. M. de C., Portari, G. V., \& Jordão, A. A. (2009). Determinação do valor energético de hambúrgueres e almôndegas através da calorimetria direta e da composição centesimal. Comparação 
com informações nutricionais apresentadas nas embalagens. Bioscience Journal, 25(5), 141-148.

Lim, J. (2011). Hedonic scaling : a review of methods and theory. Food Quality and Preference, 22(8), 733-747. http://dx.doi.org/10.1016/j. foodqual.2011.05.008.

Maietta, O. W., \& Gorgitano, M. T. (2016). School meals and pupil satisfaction: evidence from Italian primary schools. Food Policy, 62, 41-55. http://dx.doi.org/10.1016/j.foodpol.2016.04.006.

Medeiros, C. C. M., Cardoso, M. A. A., Pereira, R. A. R., Alves, G. T. A., França, I. S. X., Coura, A. S., \& Carvalho, D. F. (2011). Nutritional status and habits of life in schoolchildren. Revista Brasileira de Crescimento Desenvolvimento Humano, 21(83), 789-797.

Memon, N. N., Talpur, F. N., Bhanger, M. I., \& Balouch, A. (2011). Changes in fatty acid composition in muscle of three farmed carp fish species (Labeo rohita, Cirrhinus mrigala, Catla catla) raised under the same conditions. Food Chemistry, 126(2), 405-410. http:// dx.doi.org/10.1016/j.foodchem.2010.10.107.

Merril, A. L., \& Watt, B. K. (1973). Energy value of foods: basis and derivation (74 p.). Departament of Agriculture.

Mitterer-Daltoé, M. L., Latorres, J. M., Queiroz, M. I., Fiszman, S., \& Varela, P. (2013b). Reasons underlying low fish consumption where availability is not an issue: a case study in Brazil, one of the world's largest fish producers. Journal of Sensory Studies, 28(3), 205-216. http://dx.doi.org/10.1111/joss.12037.

Mitterer-Daltoé, M. L., Queiroz, M. I., Fiszman, S., \& Varela, P. (2014). Are fish products healthy? Eye tracking as a new food technology tool for a better understanding of consumer perception. LebensmittelWissenschaft + Technologie, 55(2), 459-465. http://dx.doi.org/10.1016/j. lwt.2013.10.013.

Mitterer-Daltoé, M., Latorres, J., Treptow, R., Pastous-Madureira, L., \& Queiroz, M. (2013a). Acceptance of breaded fish (Engraulis anchoita) in school meals in extreme southern Brazil. Acta Alimentaria, 42(2), 275-282. http://dx.doi.org/10.1556/AAlim.42.2013.2.15.

Müller, H., \& Hamm, U. (2014). Stability of market segmentation with cluster analysis: a methodological approach. Food Quality and Preference, 34, 70-78. http://dx.doi.org/10.1016/j.foodqual.2013.12.004.

Myrland, Ø., Trondsen, T., Johnston, R., \& Lund, E. (2000). Determinants of seafood consumption in Norway: lifestyle, revealed preferences, and barriers to consumption. Food Quality and Preference, 11(3), 169-188. http://dx.doi.org/10.1016/S0950-3293(99)00034-8.

Naes, V., Brockhoff, P., \& Tomic, O. (2010). Statistics for sensory and consumer science. Hoboken: John Wiley \& Sons.

Nestel, P., Clifton, P., Colquhoun, D., Noakes, M., Mori, T., Sullivan, D., \& Thomas, B. (2015). Indications for Omega-3 long chain polyunsaturated fatty acid in the prevention and treatment of cardiovascular disease. Heart Lung and Circulation, 24(8), 769-779. PMid:25936871. http://dx.doi.org/10.1016/j.hlc.2015.03.020.

Onwezen, M. C., \& van der Weele, C. N. (2016). When indifference is ambivalence: strategic ignorance about meat consumption. Food Quality and Preference, 52, 96-105. http://dx.doi.org/10.1016/j. foodqual.2016.04.001.

Osowski, C. P., Göranzon, H., \& Fjellström, C. (2013). Teachers' interaction with children in the school meal situation: the example of pedagogic meals in Sweden. Journal of Nutrition Education and Behavior, 45(5), 420-427. PMid:23768894. http://dx.doi.org/10.1016/j. jneb.2013.02.008.
Peryam, D. R., \& Pilgrim, F. J. (1957). Hedonic scale method of measuring food preference. Food Technology, 11, 9-14.

Peterson, M. L., Christou, E., \& Rosengren, K. S. (2006). Children achieve adult-like sensory integration during stance at 12-yearsold. Gait \& Posture, 23(4), 455-463. PMid:16002294. http://dx.doi. org/10.1016/j.gaitpost.2005.05.003.

Pilon, G., Ruzzin, J., Rioux, L.-E., Lavigne, C., White, P. J., Frøyland, L., Jacques, H., Bryl, P., Beaulieu, L., \& Marette, A. (2011). Differential effects of various fish proteins in altering body weight, adiposity, inflammatory status, and insulin sensitivity in high-fat-fed rats. Metabolism: Clinical and Experimental, 60(8), 1122-1130. PMid:21306751. http://dx.doi.org/10.1016/j.metabol.2010.12.005.

Popper, R., \& Kroll, J. J. (2005). Issues and viewpoints conducting sensory research with children. Journal of Sensory Studies, 20(1), 75-87. http://dx.doi.org/10.1111/j.1745-459X.2005.00007.x.

Sampels, S. (2015). The effects of processing technologies and preparation on the final quality of fish products. Trends in Food Science \& Technology, 44(2), 131-146. http://dx.doi.org/10.1016/j. tifs.2015.04.003.

Sartori, A. G. O., \& Amancio, R. D. (2012). Pescado: importância nutricional e consumo no Brasil. Segurança Alimentar e Nutricional, 2(11), 83-93.

Simões, D. R. S., Pedroso, M. A., Ruiz, W. A., \& Almeida, T. L. (1998). Hambúrgueres formulados com base protéica de pescado. Food Science and Technology (Campinas), 18(4), 1-15. http://dx.doi. org/10.1590/S0101-20611998000400011.

Soares, K. M. de P., \& Gonçalves, A. A. (2012). Qualidade e segurança do pescado. Revista Do Instituto Adolfo Lutz (Impresso), 71(1), 1-10.

Torres, E. A. F. S., Rimoli, C. D., Olivo, R., Hatano, M. K., \& Shimokomaki, M. (1998). Papel do sal iodado na oxidação lipídica em hambúrgueres bovino e suíno (misto) ou de frango. Food Science and Technology (Campinas), 18(1), 108-120. http://dx.doi.org/10.1590/S010120611998000100011.

Torres, E. A. F., Campos, N. C., Duarte, M., Garbelotti, M. L., Philippi, S. T., \& Minazzi-Rodrigues, R. S. (2000). Composição centesimal e valor calórico de alimentos de origem animal. Food Science and Technology (Campinas), 20(2), 145-150. http://dx.doi.org/10.1590/ S0101-20612000000200003.

Tuorila, H., Huotilainen, A., Lähteenmäki, L., Ollila, S., Tuomi-Nurmi, S., \& Urala, N. (2008). Comparison of affective rating scales and their relationship to variables reflecting food consumption. Food Quality and Preference, 19(1), 51-61. http://dx.doi.org/10.1016/j. foodqual.2007.06.007.

Tuorila, H., Palmujoki, I., Kytö, E., Törnwall, O., \& Vehkalahti, K. (2015). School meal acceptance depends on the dish, student, and context. Food Quality and Preference, 46, 126-136. http://dx.doi. org/10.1016/j.foodqual.2015.07.013.

Universidade Federal de São Paulo - UNIFESP. (2010). Manual para aplicação dos testes de aceitabilidade no Programa Nacional de Alimentação Escolar (57 p.). Santos: UNIFESP.

Wei, W., \& Miao, L. (2013). Effects of calorie information disclosure on consumers' food choices at restaurants. International Journal of Hospitality Management, 33(1), 106-117. http://dx.doi.org/10.1016/j. ijhm.2012.06.008. 